\title{
The Influence of Health Counseling on Family Knowledge about Recovery of Pulmonary Tb Patients in The Working Area of Puskesmas Burau
}

\author{
Lestari Lorna Lolo' ${ }^{1}$, Romi RS ${ }^{1}$ \\ 1) Nursing Department at Kurnia Jaya Persada College of Health Sciences \\ thenextambition1@gmail.com
}

DOI: http://doi.org/10.29080/jhsp.v3i3S.274

\section{Key Words}

Health

Counseling ;

Knowledge;

Family of TB

patients

\begin{abstract}
Pulmonary tuberculosis is a direct infectious disease caused by TB germs (mycobacterium tuberculosis). Health problems experienced by one family member can affect other family members, especially families who care for TB patients known as infectious diseases, so families are required to understand pulmonary TB as a whole. However, families who care for TB patients still lack understanding about recovery of the pulmonary TB patients. The purpose of the study was to analyze the influence of health counseling on family knowledge about recovery of pulmonary TB patients in the working area of Puskesmas. The kind of research is quantitative using the pre-experimental design of one group prepost test. The subject of research were families who treated TB patients in the working area of Puskesmas Burau. Interventions got by providing health counseling using leaflets. Data collection method used a questionnaire. The results of the study used paired samples T-test with a calculated value for the influence of health counseling on family knowledge about recovery of pulmonary TB patients obtained $p$-value $=0,000$ smaller than the value of $p$-value $=0.05$. From the analysis can be interpreted that Ha is accepted and HO rejected or there was an effect of health counseling on family knowledge about recovery of pulmonary TB patients. The suggestion of research is suggested to the health center to keep improving the health counseling routines that have been conducted and to modify the counseling method so that TB patients and families are not saturated with the provision of information about pulmonary $T B$.
\end{abstract}

\section{Introduction}

Tuberculosis (TB) is an infectious disease caused by mycobacterium tuberculosis. These germs are considered the most dangerous in the health world that attacks the lungs. Myycobacterium tuberculosis germs also attack the outside of the lungs such as lymph nodes glands), skin, intestines/digestive tract, brain membranes, and bones ${ }^{10}$. The main symptoms of pulmonary tuberculosis include coughing for 2 weeks or more, coughing accompanied by additional symptoms of phlegm, sputum mixed with blood, shortness of breath, weakness, decreased appetite, weight loss, malaise, night sweats without physical activity, and more fever from 1 month (1).

In 2013, there were 6.1 million cases and 5.7 million cases as new and relapsing cases and 0.4 million cases that had received treatment. The incidence of TB cases globally has decreased for several years. From 2000 to 2013, the incidence has decreased by an average of 1.5\% each year. The TB mortality rate and prevalence rate also decreased between 1990 and 2013. The reduction in the estimated mortality rate was $45 \%$ and the prevalence rate was $41 \%$. Indonesia is one of the six countries with the highest number of new cases of positive smear TB with amounts of 420,000-520,000 (2).

In 2013, it was estimated that from 2.6 million cases of pulmonary TB, 300,000 were cases of MDR TB. Today the number of MDR TBs worldwide is 480,000 $(350,000-610,000)$ and it is estimated 210,000 will die because of this. Indonesia is one of the 10 countries that has the most MDR TB cases by being ranked 8th. Besides Indonesia, the other countries that have the most MDR TB cases are China, India, Myanmar, Pakistan, Philippines, Russian Federation, South Africa, Ukraine, and Uzbekistan. During 2011 MDR TB cases in Indonesia were reported to have 260 cases and it is estimated that in 2013, 1,800 cases will be detected.(3)

The risk of contracting depends on the level of exposure to sputum with pulmonary TB patients with positive, smear giving the possibility of a greater risk of transmission than pulmonary TB with the negative smear. The risk of transmission each year is shown by the Annual Risk of Tuberculosis Infection 
(ARTI), which is the proportion of the population at risk of being infected with TB for one year. ARTI of $1 \%$ means that 10 (ten) of the 1000 residents are infected every year. According to WHO, ARTI Indonesia varies between $1-3 \%$. TB infection is proven by changes in the negative tuberculin reaction to being positive (4).

The number of deaths from TB is estimated at 61,000 deaths annually (5). The results of the 2004 TB prevalence survey regarding knowledge, attitudes, and behavior showed that $96 \%$ of families cared for family members suffering from TB and only 13\% hid their existence. Although $76 \%$ of families have heard of TB and $85 \%$ know that TB can be cured, only $26 \%$ can name two main symptoms of TB. The method of transmission of TB is understood by $51 \%$ of families and only $19 \%$ know that free TB drugs are available ${ }^{2}$. The results of the survey show that there are still families who do not yet have sufficient knowledge about tuberculosis.

The family becomes the leading health care unit in improving community health status. If every family is healthy, a healthy community will also be created. Health problems experienced by one family member can affect other family members, affecting the family system, the local community, and even the global community. Thus, family health and independence are the main keys to community health development ${ }^{3}$. The form of coaching that is carried out on families with pulmonary TB is to make visits and direct contact to target activities. The smallest functional unit in the provision of family nursing care is family, where the participation of family members in the provision of family nursing care greatly affects the results of family nursing care (6).

Based on the initial survey conducted in the work area of Puskesmas Burau, there were eight patients suspect and TB found six people, including those who did not understand the recovery of pulmonary TB patients and two people already understood about the recovery of pulmonary $\mathrm{TB}$. Based on this, the researchers were interested in conducting research on the influence of health counseling on family knowledge about the recovery of pulmonary TB patients in the work area of Puskesmas Burau. Puskesmas (Community Health Centre) are government-mandated community health clinics located across Indonesia. This is done to increase the level of knowledge of family members about the recovery of pulmonary TB patients to improve treatment compliance and motivation to recover in TB patients.

Based on the description of the background, the researcher formulated a mass formula of research, namely the influence of health education on family knowledge about the recovery of pulmonary TB patients in the work area of PuskesmasBurau.

\section{Method}

The type of research is the quantity using the research method used in this study is a quasiexperiment one group pre and post-test design. The population and sample in this study were 35 respondents. The sampling procedure used the total sampling method. The place of research in the work area of Puskesmas Burau. This research was conducted for one month in September 2016

\section{Results}

\section{Characteristics of Respondents}

Table 1 Frequency distribution characteristic of respondents in the Work Area of Puskesmas Burau, District Wotu, East Luwu Regency in 2016

\begin{tabular}{lcc}
\hline \multicolumn{1}{c}{ characteristics } & f & (\%) \\
\hline Usia & & \\
Adult & 25 & 71.4 \\
Elderly & 10 & 28.6 \\
Gender & & 51.4 \\
Man & 18 & 48.6 \\
Women & 17 & \\
Medical diagnosis & & \\
Positive TB & & 48.6 \\
Suspect TB & 17 & 51.4 \\
\hline Total & 18 & 100.0 \\
\hline
\end{tabular}

This study involved 35 respondents with a distribution of respondents based on adult age as many as 25 people (71.4\%) and the age of the elderly as many as 10 (28.6\%). Based on gender, there was male sex as many as 18 people ${ }^{*} 51.4 \%$ ) and female sex as many as 17 people (48.6\%). Data on the 
frequency distribution of medical diagnosis of positive TB were 17 people (48.6\%) and suspect TB as many as 18 people $(51.4 \%)$.

\section{Distribution of Respondent Answer Before and after the intervention}
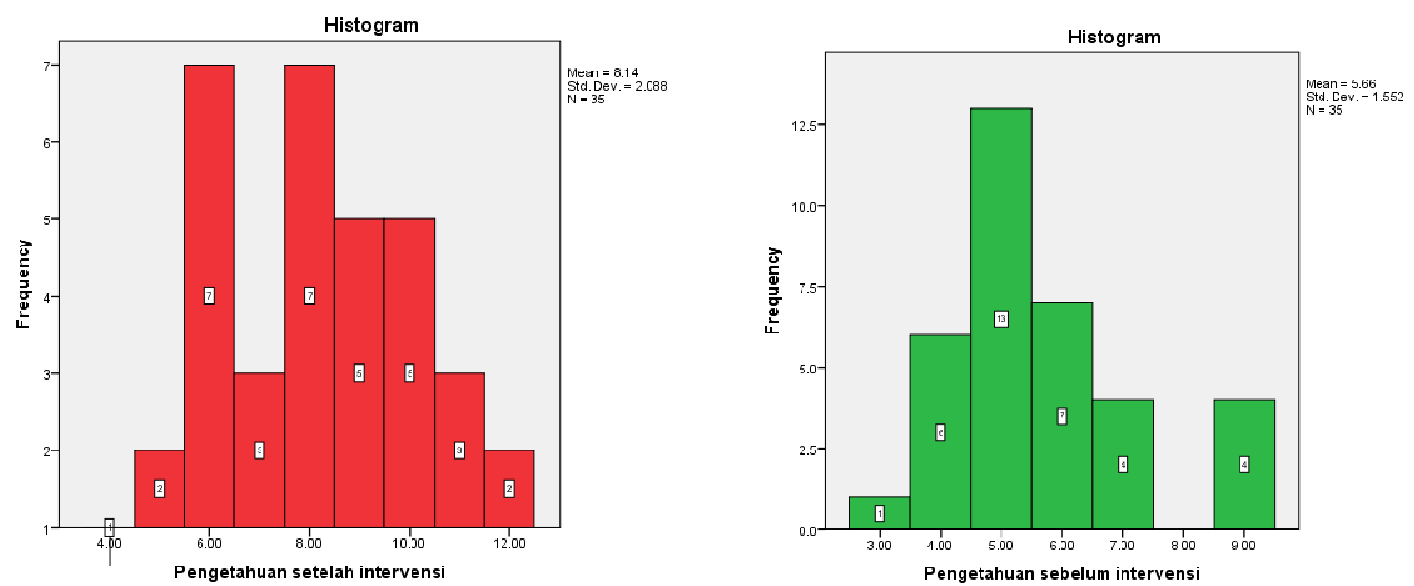

\section{Distribution of Respondent Answers Based on Knowledge Level before and after intervention in the Work Area of PuskesmasBurau, District Wotu, East Luwu Regency in 2016}

This research was conducted with a total sample of 35 people. Based on the data, of 35 respondents, there were 29 respondents who experienced an increase in the score of the correct answer and 6 respondents who did not experience an increase in the score of the correct answer.

\section{Description of Knowledge}

Table 3 Distribution of Respondents Based on Pre Test Knowledge in the Work Area of PuskesmasBurau, District Wotu, East Luwu Regency in 2016

\begin{tabular}{lcccc}
\hline Knowledge & F & $(\%)$ & F & $(\%)$ \\
\hline High & 9 & 25.7 & 24 & 68.6 \\
Low & 26 & 74.3 & 11 & 31.4 \\
\hline Total & 35 & 100.0 & 35 & 100.0
\end{tabular}

Data on the frequency pre-knowledge distribution data were 9 people $(25.7 \%)$ and low knowledge were 26 people (74.3\%). Data on post-test knowledge distribution frequency with high knowledge were 24 people (68.6\%) and low knowledge as many as 11 people (31.4\%).

\section{Bivariate Analysis Effect of Health Counseling on Family Knowledge About Patient Recovery for Pulmonary TB}

Table 5 Statistic Paired Samples T-test. The influence of health Counselingon Family Knowledge About Patient Recovery of Pulmonary TB in the Work Area of Puskesmas Burau, District Wotu, East Luwu Regency in 2016

\begin{tabular}{|l|c|c|}
\hline & Before intervention & After intervention \\
\hline Mean & 26.405 & 26.405 \\
\hline Std. Deviation & 0.80601 & 0.80601 \\
\hline Correlation & \multicolumn{2}{|c|}{0.468} \\
\hline Sig. & 0.005 \\
\hline P value & \multicolumn{2}{|c|}{0.000} \\
\hline
\end{tabular}


Based on the above data, shows the mean value or the average posttest 8.1176 value which is greater than the pre-test value which is 2.6405. The post-intervention standard deviation value was 2.11438 greater than the pre-intervention standard deviation value of 0.80601 . Based on the sig value, obtained a value of 0.005 which means that there is a significant relationship of knowledge before and after counseling.

Based on the paired Samples T-test by obtaining a calculated value for the influence of health counseling on knowledge in the family of pulmonary TB patients the value $p=0,000$ is greater than the value of $\alpha=0.05$, so the hypothesis decision is Ha accepted or there is an influence of health counseling on knowledge in family of pulmonary TB patients.

\section{Discussion}

From the results of the study, it was found that the data on the frequency distribution of knowledge before the intervention was 9 people (25.7\%) and low knowledge as many as 26 people (74.3\%). The low level of knowledge of respondents at the time of the study even though the Puskesmas had routinely provided counseling but the respondents still had knowledge that was not in accordance with the measurements in this study. Knowledge is the formation of associative thinking that connects or interweaves a thought with reality or with other thoughts based on repeated experiences without an understanding of intrinsic and universal causality (7).

From the results, of the research carried out data on the frequency distribution of knowledge after the intervention with high knowledge as many as 24 people (68.6\%) and low knowledge as many as 11 people (31.4\%). High knowledge from respondents was obtained because respondents had been given health education. Besides that respondents had also been well exposed to health education routinely carried out by the health center.

Based on the above data, it is indicated/shown the mean value or the average post-test 8.1176 value which is greater than the pretest value which is 2.6405 . The post-intervention standard deviation value was 2.11438 greater than the pre-intervention standard deviation value of 0.80601 . Based on the Independent Samples Test t-test by obtaining a calculated value for the influence of health counseling on knowledge in the family of pulmonary TB patients the value $p=0,000$ is greater than the value of $\alpha=0.05$, so the hypothesis decision is Ha accepted or there is an influence of health counseling on knowledge in family of pulmonary TB patients.

In this study, it is found that an increase in respondents' knowledge that is high knowledge before the intervention of 9 people (25.7\%) before the intervention increased to 24 people $(68.6 \%)$ after the intervention. Based on the results of the study, an increase in knowledge was found in respondents aged 29 years and over to the elderly. Age is a person's lifetime, the longer the age of the more experience they have. The more mature a person is, the wiser he takes in making a decision, including receiving information to increase knowledge. This is in accordance with what was conveyed by Dharmawati, that the more mature the level of maturity and strength of a person will be more mature in thinking ${ }^{14}$. Notoatmojo explains that knowledge is the result of knowing and value occurs after people do sensing an object, including through health counseling (7). In addition to age factors, Budiman (2013) states that knowledge is influenced by factors of education, information/mass media, socio-cultural and economic, environment, experience, attitudes (5).

The results of this study are in line with the results of research conducted by Palupi (2013) which shows that the value of $p=0.004(<0.05)$ which means that there is a relationship between knowledge before and after giving counseling (8). The results of this study are supported by the results of research conducted by Handayani (2011) which states that there is an influence of health education in the treatment group on community knowledge about prevention of pulmonary tuberculosis with $\mathrm{p}=0.001$ (9).

Based on the results of this research, researchers assume that health education can provide a change of knowledge for the community. Health counseling should pay attention to the technique or method of delivery, the material provided, the target recipient and the age of the recipient of the information, so that the material delivered is right on target and well received.

The method of collecting data with a self-evaluative questionnaire allows respondents to provide answers that are subjective, so that researchers emphasize informed consent before the patient's family answers the questionnaire so that its subjective value can be reduced. The results of this study found that 
there was an effect of health education on family knowledge about the recovery of pulmonary TB patients. Therefore, health workers in this case nursing staff should carry out their functions as educators to provide information through health counseling carried out by providing good, interesting material right on target, and pay attention to the age of the recipient of the material.

\section{Conclusions and Suggestions Conclusion}

1. Data on pre-test knowledge distribution frequency with high knowledge were 9 people $(25.7 \%)$ and low knowledge were 26 people (74.3\%).

2. Data on post-test knowledge distribution frequency with high knowledge were 24 people (68.6\%) and low knowledge as many as 11 people (31.4\%).

3. Based on the Independent Samples Test t-test, it was concluded that there was an effect of health education on knowledge in families of pulmonary TB patients $(0,000)$.

\section{Suggestion}

1. TB patients and families are advised to maintain and increase the knowledge they have acquired and apply this knowledge so that pulmonary TB disease can be treated as much as possible so that patients recover and prevent TB recurrence in patients.

2. Based on the results of the study, it was suggested to the health center to continue to improve the health counseling routine that had been done but change or modify the counseling method so that patients and families of TB were not saturated with the provision of information about pulmonary TB.

3. This research is able to open new insights for researchers and other researchers so that in the future, it can examine other factors or use other methods in providing health counseling, among others, providing counseling using posters, videos, and others.

\section{References}

1. Badan Penelitian dan Pengembangan Kesehatan Kementerian RI Tahun 2013. Riset Kesehatan Dasar (Riskesdas) 2013 [Internet]. Available from:

http://www.depkes.go.id/resources/download/general/Hasil\%20Riskesdas\%20 2013.pdf.

2. World Health Organization. Global Tuberculosis Report 2014 [Internet]. 2014. Available from: http://www.who.int/tb/publications/globalreport/gtbr14main_text.pdf.

3. World Health Organization. Multi Drug Resistant (MDR TB) 2014 update. [Internet]. 2014. Available from: http://www.who.int/tb/challenges/mdr/mdr_tb_factsheet.

4. Kementerian Kesehatan RI. Strategi Nasional Pengendalian TB. Jakarta; 2011.

5. Budiman, A Riyanto. Kapita Selekta Kuisioner Pengetahuan dan Sikap Dalam Penelitian Kesehatan. Jakarta: Salemba Medika; 2013.

6. Efendi F. Keperawatan kesehatan komunitas: teori dan praktik dalam keperawatan. Jakarta: Salemba Medika; 2013.

7. Notoatmojo S. Promosi kesehatan dan Perilaku Kesehatan. Jakarta: Rineka Cipta; 2012.

8. Paluppi. Pengaruh Pendidikan KesehatanTerhadap Perubahan Pengetahuan,Sikap Dan Perilaku Penderita Tuberculosis Yang Berobat Di Wilayah Kerja Puskesmas Surakarta. [Surakarta]: Pasca Sarjana Universitas Sebelas Maret; 2013.

9. Tri Etik Handayani. Pengaruh Pendidikan Kesehatan Terhadap Tingkat Pengetahuan dan Sikap Masyarakat tentang Pencegahan Tuberkulosis Paru di Dusun Kayangan Kecamatan Karang Anyar. UniversitasMuhammadiyah Surakarta; 2011. 